\title{
DETERMINANTS OF MICRO AND SMALL ENTERPRISE FOOD INDUSTRY MARKET EXPANSION IN INDONESIA
}

\author{
Amzul Rifin*1 \\ *) Department of Agribusiness, Faculty of Economics and Management, IPB University \\ Jl. Agatis, IPB Darmaga Campus, Bogor 16680
}

\begin{abstract}
One of the indicators that might upgrade micro and small enterprise is the ability to expand their market target outside their location or district. The objective of this article was to analyze the determinants of market expansion for small and medium enterprise especially in the food industry in Indonesia. Market expansion is defined as selling products or services outside the district where the enterprise is located. Secondary data were utilized in the research by using the Micro and Small Enterprise Survey conducted by Statistics Indonesia in 2014 with the data of 21,380 firms. Two analysis were conducted, firstly using the logit analysis in order to differentiate between enterprises selling their products inside and outside the district. The second analysis used Tobit analysis of which the dependent variable is the share of product sold outside the district. Independent variables used in both equations are similar. The results indicated that higher education level, number of labor, value of production, number of enterprise with external finance, number of enterprise located in Java and male-owned firms resulted in higher probability of selling their product outside the district. Moreover, the same variables will also increase the share of product sold outside the district. From the two equations, it can be concluded that the government policy must be addressed in two aspects in order to upgrade the small and medium enterprises, the first is increasing the scale of the enterprises and secondly, fostering financial inclusion for these enterprises.
\end{abstract}

Keywords: micro and small enterprise, logit analysis, tobit analysis, food industry, market expansion

\begin{abstract}
Abstrak: Salah satu indikator upgrading usaha mikro dan kecil (UMK) adalah kemampuan untuk memperluas pasar ke luar kota atau kabupaten. Tujuan dari artikel ini adalah untuk menganalisis faktor-faktor yang menentukan perluasan pasar usaha kecil dan menengah pada sector makanan di Indonesia. Perluasan pasar didefinisikan sebagai menjual produk atau jasa di luar kota atau kabupaten dimana UMK itu berada. Data sekunder digunakan dalam penelitian ini bersumber dari Survei Usaha Mikro dan Kecil yang dilakukan oleh Badan Pusat Statistik (BPS) pada tahun 2014 dengan jumlah usaha sebanyak 21.380 usaha. Dua analisis dilakukan, pertama menggunakan analisis logit untuk membedakan antara usaha yang menjual produknya di dalam dan diluar kabupatan/kota. Analisis kedua menggunakan Tobit dimana variable dependennya berupa pangsa produk yang dijual ke luar kabupaten/kota. Variabel independent yang digunakan pada kedua persamaan tersebut sama. Hasil kedua persamaan tersebut menunjukkan bahwa semakin tinggi tingkat pendidikan, jumlah tenaga kerja, nilai produksi, pembiayaan eksternal, UMK di Jawa dan UMK dengan pengusaha laki-laki memiliki probabilitas yang lebih tinggi untuk menjual ke luar kabupaten/kota dan akan meningkatkan pangsa produk yang dijual keluar kabupaten/kota. Kebijakan pemerintah yang dapat diambil menyangkut dua hal untuk mengupgrade UMK yaitu peningkatan skala ekonomi dan peningkatan akses terhadap pembiayaan eksternal.
\end{abstract}

Kata kunci: UMK, analisis logit, analisis logit, sector makanan, perluasan pasar

\footnotetext{
${ }^{1}$ Corresponding author:

Email: amzul@apps.ipb.ac.id
} 


\section{INTRODUCTION}

In Indonesia, the types of enterprise are differed by the number of workers. Enterprise with workers less than four person is considered as micro enterprise. Meanwhile, it is called as small enterprise when the number of workers is between five until 19 workers including the owner. The contribution of small and micro enterprise in Indonesian economy was relatively small, only $43.08 \%$ of total constant GDP in 2013. Although in terms of number, $99.9 \%$ of total enterprises in Indonesia are small and micro enterprises and $93.63 \%$ of labors are working in those enterprises (Ministry of Cooperative and Small Medium Enterprise, 2014).

Tambunan (2008a) mentioned several problems faced by the micro and small enterprise causing relatively small contribution of the micro and small enterprise to the Indonesian economy. These problems are lack of capital, difficulties in procuring raw materials, lack of access to relevant business information, difficulties in marketing and distribution, low technological capabilities, high transportation costs, communication problems, problems caused by cumbersome and costly bureaucratic procedures and policies and regulations that generate market distortions. One of the problems is marketing, according to Tambunan (2008a), the small and micro enterprises mainly depend on their trading partners for selling their products through subcontracting or order from customers. According to survey conducted by Statistics Indonesia, problem in marketing is the second biggest problem faced by the small and micro enterprise which amounted to $25 \%$. Meanwhile the biggest problem is capital (38.84\%). Although many problems are faced by Indonesia's small and micro enterprises in marketing, several of them has succeeded in exporting their products. Statistics Indonesia (2015) indicated that $0.1 \%$ of the small and micro enterprises have exported their products while the majority sell their products inside the district $(89.45 \%)$.

One of the issues in small and medium enterprise marketing is selecting a market to sell their product which concerns the firm's market expansion. Many works have been done to gain foreign market. Brewer (2001) indicated that small and medium enterprises choose their market based on three aspects, namely business factors, chance and distance. In addition, how the small and medium enterprises enter the foreign market can be classified into two modes, systematic international market selection (SIMS) and non systematic international market selection.

Yip, Biscarri and Monti (2000) defined systematic international market selection (SIMS) as using objective criteria in selecting export markets which included activities such as systematic and formalized international market research activities in selecting suitable markets abroad, visits of foreign markets on fact-finding tours before entry, monitoring of national and international business press for product-related activities, and the use of published statistical sources in differentiating foreign markets. Brouthers and Nakos (2005) confirmed that small and medium enterprise which used a systematic international market selection (SIMS) will perform better in the international market. Meanwhile, most small and medium enterprises conducted a non-systematic international market selection such as pulled by business partners to be subcontactors when they obtain projects in foreign countries (Westhead et al. 2002) or it can be that a domestic client established a foreign operations (Brewer, 2001).

Another approach is determining the variables that can differentiate firm with export and non export activities, these variables include number of employees (Javalgi, White and Lee, 2000; Silvente, 2005; Bernard and Jensen, 1999), total sales (Javalgi, White and Lee, 2000; Silvente, 2005; Bhavani and Tendulkar, 2001; Lee and Habte-Giorgis, 2004), age of firm (Javalgi, White and Lee, 2000), firm ownership (Javalgi, White and Lee, 2000; Sjoholm, 2003), industry type (Javalgi, White and Lee, 2000); innovation (Pla Barber and Alegre, 2007), wages or share of wages (Silvente, 2005; Bhavani and Tendulkar, 2001; Bernard and Jensen, 1999) and imported inputs (Bas and Straus-Kahn, 2010; Aristei et al. 2013).

Most of the literature on market selection and market expansion are on foreign markets, very few discuss on domestic market especially for small and medium enterprise. On the other hand, decision of market expansion on farmers has been analyzed among others by Faschamps and Hill (2005), Shilpi and UmaliDeininger (2008) and Panda and Sreekumar (2012). Faschamps and Hill (2005) studied the determinants of coffee farmer in Uganda to sell their coffee in farmgate or travel to market. The results revealed that selling to the market was likely conducted when the quantity is large, while wealthy farmers were less likely to sell their coffee to the market. Moreover, Shilpi and Umali- 
Deininger (2008) revealed that farmers will expand their market when the market facilities are improved and there is decreasing time to travel to the market. Meanwhile Panda and Sreekumar (2012) indicates that there are four variables that can shift farmer marketing channel from nonmarket participation to formal market participation, this variables are access market to information, adding value and grading the produce, infrastructure and guaranteed market.

The objective of this article was to analyze the determinants of small and micro enterprise to conduct market expansion which is indicated by selling their products outside the district, in the food and beverage industry. The food and beverage industry was selected since $78.4 \%$ of Indonesia's small and micro enterprises in 2015 were operated in this industry.

\section{METHODS}

This study utilized secondary data collected by Statistics Indonesia through the Micro and Small Firm Survey conducted in 2014 which focused on the food and beverage industry with 21,380 firms included in the observation. The determinant of market expansion was classified based on Storey (1994) regarding the key components in analyzing the growth of small and medium enterprise. These key components were characteristics of entrepreneur, characteristics of SME and contextual variables. Variables included in characteristics of entrepreneur were age, education and gender; characteristics of SME included years established, number of labor, value of production and partnership meanwhile for contextual variables consisted of external finance and partnership.

This study utilized two models, namely logit and tobit model. The logit model is used since the dependent variable is in the form of dummy (Gujarati, 2015). The dependent variable is defined as one when majority of the product (more than 50\%) is sold outside the district, meanwhile it is zero when the firm sell inside the district. The data showed that only $8 \%$ of the firms sold their majority of the product outside the district and the rest sold the majority of the product inside the district.

In the tobit model, the dependent variable is the share of product sold outside the district. Tobit model is used since the dependent variable has minumum and maximum value or the data are censored (Gujarati, 2015). The average share of product sold outside the district was only $7.5 \%$. In addition, $88.5 \%$ of the firms sold their product only inside the district and the rest expanded their market by selling outside the district. In both models, the independent variable is similar which is as follows:

Logit Model

$$
\begin{gathered}
\mathrm{L}_{\mathrm{i}}=\alpha_{1} \mathrm{YR}_{\mathrm{i}}+\alpha_{2} \mathrm{AGE}_{\mathrm{i}}+\alpha_{3} \mathrm{EDU}_{\mathrm{i}}+\alpha_{4} \mathrm{LAB}_{\mathrm{i}}+\alpha_{5} \mathrm{PROF}_{\mathrm{i}}+ \\
\alpha_{8} \mathrm{DPART}_{\mathrm{i}}+\alpha_{9} \mathrm{DLOC}_{\mathrm{i}}+\varepsilon_{\mathrm{i}}
\end{gathered}
$$

Tobit Model

$$
\begin{aligned}
\mathrm{T}_{\mathrm{i}}= & \alpha_{0}+\alpha_{1} \mathrm{YR}_{\mathrm{i}}+\alpha_{2} \mathrm{AGE}_{\mathrm{i}}+\alpha_{3} \mathrm{EDU}_{\mathrm{i}}+\alpha_{4} \mathrm{LAB}_{\mathrm{i}}+ \\
& \alpha_{5} \mathrm{PROF}_{\mathrm{i}}+\alpha_{8} \mathrm{DPART}_{\mathrm{i}}+\alpha_{9} \mathrm{DLOC}_{\mathrm{i}}+\varepsilon_{\mathrm{i}}
\end{aligned}
$$

Description: L (market location $(1=$ selling outside district; $0=$ selling inside district)); $\mathrm{T}$ (share of product sold outside the district); YR (number of years the firm established (years)); AGE (age of entrepreneur (years)); EDU (education of entrepreneur (years)); LAB (number of production labor (person)); PROD (value of production (million Rp)); DGEN (dummy for gender of entrepreneur $(1=\operatorname{man} ; 0=$ woman $))$; DFIN (dummy for external finance $(1=$ firm with external finance; $0=$ firm without external finance)); DPART (dummy for partnership ( $1=$ firm with partnership; 0 = firm without partnership)); DLOC (dummy for firm location ( 1 = located in Java island; $0=$ located outside Java island)).

The hypothesis used for all the coefficients in both models were positive. The data description showed that firm selling outside district had older firm establishment, higher education of entrepreneur, higher number of production labor and higher value of production, meanwhile older entrepreneur tended to sell their products inside district (Table 1). Older firm establishment means that the firm has more experience especially in selling the product outside the district. Greater number of production labor and value of production indicates that the firm has higher capacity therefore need to sell their product outside the district to expand their market. Meanwhile, younger entrepreneur and higher education level make entrepreneurs become more risk taker to sell their products outside the district. 
In addition, the average difference between firm selling outside and inside the district was relatively small on firm establishment and age of entrepreneurs while the other three variables had higher average difference. Testing the difference between both market locations was done using t-test, it showed that two variables were not statistically different at 5\% significance level between selling outside and inside the district. These two variables were firm establishment and age of entrepreneur. Meanwhile, the other three variables were difference in means between the two market locations (Table 1).

Table 1. Data Description

\begin{tabular}{lcc}
\hline \multirow{2}{*}{ Variables } & \multicolumn{2}{c}{ Market location } \\
\cline { 2 - 3 } & Outside regency & Inside regency \\
\hline $\begin{array}{l}\text { Average Firm } \\
\text { Establishment (years) }\end{array}$ & 14.84 & 14.45 \\
$\begin{array}{l}\text { Average Age of } \\
\text { Entrepreneur (years) }\end{array}$ & 46.69 & 46.89 \\
$\begin{array}{l}\text { Average Education of } \\
\text { entrepreneur (years)* }\end{array}$ & 8.21 & 7.79 \\
$\begin{array}{l}\text { Average Number } \\
\text { of production labor } \\
\text { (person)* }\end{array}$ & 3.71 & 2.23 \\
$\begin{array}{l}\text { Average Value of } \\
\text { production (million }\end{array}$ & 43.91 & 10.07 \\
Rp)* & & \\
\hline
\end{tabular}

Note: $*$ different at 5\% significance level

In this article, the focus is on modeling the firm's decision to sell outside the district. The firm's decision to sell outside the district is assumed to be led by farmer's willingness to maximize their profit and based on several factors (Doll and Orazem, 1984).

Following the approach of Arinloye et al. (2014) in marketing channel selection, it is assumed that a firm's decision to sell its product outside the district is derived from the maximization of expected utility or profit the firm gained from selling outside the district. This utility is a function of a vector of factors , unknown parameters $\beta_{\mathrm{r}}$, and an error term $\varepsilon$, assumed to be independent $\mathrm{N}(0, \sigma 2)$ (Equation 1). It is expected that firms will decide to sell outside or inside the district that shows the most positive utility. The expected difference in utility is calculated as follows:

$$
U_{j}=\left[\pi_{i j}^{R}-\pi_{i j}^{I}\right]=X_{r}^{R} \beta_{r}+\varepsilon^{R}
$$

where $\mathrm{Uj}$ is the unobserved expectation operator representing the expected utility difference, is the utility derived from choosing to sell to outside the district if selected by firms and is the utility if firms sell inside the district. Firms make a subjective comparison between selling the product outside and inside the district. Firms choose to sell outside the district only when it is assumed to receive higher profit. From Equation 1, it can be inferred that the decision to sell outside the district is written as follows:

$$
Y_{i j}^{R}=\left\{\begin{array}{l}
1 \text { if }\left[\pi_{i}^{R}-\pi_{i}^{I}\right] \geq 0<=>X_{r}^{R} \beta_{r} \geq-\varepsilon^{R} \\
0 \text { if }\left[\pi_{i}^{R}-\pi_{i}^{I}\right]<0<=>X_{r}^{R} \beta_{r}<-\varepsilon^{R}
\end{array}\right.
$$

The decision to sell outside the district is defined as $Y_{i j}^{R}$. The choice of firm to sell outside the district $\left(Y_{i j}^{R}=1\right)$ or inside the district $\left(Y_{i j}^{R}=0\right)$ is expressed as follows:

$Y_{i j}^{R}=\left\{\begin{array}{l}1 \text { if } Y_{i j}^{R}=\alpha_{i j} X_{i j}^{R}+\varepsilon^{R} \geq 0<=>X_{r}^{R} \alpha_{i j} \geq-\varepsilon^{R} \\ 0 \text { if } Y_{i j}^{R}=\alpha_{i j} X_{i j}^{R}+\varepsilon^{R}<0<=>X_{r}^{R} \alpha_{i j}<-\varepsilon^{R}\end{array}\right.$

where $\alpha_{i j}$ is a vector of estimators and $\varepsilon^{R}$ is a vector of error terms under the assumption of normal distribution, $\mathrm{Y}^{\mathrm{R}}{ }_{\mathrm{ij}}$ is the dependent variable and $\mathrm{Y}_{\mathrm{ij}}^{\mathrm{R}}$ is the independent variables.

\section{RESULT}

The results from the two model generated similar results. Six out of nine variables were significant in explaining the determinants of market expansion. These variable were education, number ol labor, value of production, dummy for gender, dummy for external finance and dummy for location (Table 2).

For the logit model, six variables are significant. These variables are education, number of labor, value of production, gender, external finance and location. In addition, when the value of odds ratio is more than one it indicates that the variable has positive impact on the expansion. The education variable has an odds ratio of 1.065 which indicates that an increase of entrepreneur' education by one year will increase the probability of the firm to conduct market expansion by 1.065 times meanwhile from the Tobit regression it indicates that an increase of entrepreneur's education level by one year will increase the share of product sold outside district by 0.047 . The increase of education level of entrepreneur will increase the chance of the firm to 
expand outside the district and increase the share of the product sold outside the district. Higher education level of entrepreneurs will make them obtain more knowledge from their education and then will increase their capability in expanding the market. Study by Sinha (1996) in India revealed that $72 \%$ of successful entrepreneur has a minumum technical qualification while $67 \%$ of unsuccessful entrepreneur do not have any technical background.

The next significant variable was number of production labor. This variable is a proxy of firm size. The result showed that the number of production labor will increase the probability of market expansion and share of product sold outside the district. The increase of number of production labor by one person will increase the probability of market expansion by 1.159 times and the increase the share of product sold outside the district by 0.153 . This result is supported by McMahon (2001) which found larger firm has significant effect to better business performance. However, different result found by Indarti and Langerberg (2004) which discovered that firm size did not associated with business success in the case of Indonesia.

The third significant variable was the firm's value of production. The increase of value of production by one million Rupiah will increase the probability of market expansion by 1.006 times and share of product sold outside the district by 0.001 although the coefficient was relatively small for both models. Firm with higher production will need larger market to sell their product; therefore, they need to sell outside the district.
Three dummy variables significantly affected the market expansion. The first one was gender, maleowned firm will have higher probability of market expansion and share of product sold outside the district. Male-owned firm has 1.327 higher probability to conduct market expansion compare to woman-owned firm and male-owned firm share of product sold outside the district is higher 0.329 compare to woman-owned firm. This result is supported by the studies of Mazzarol et al. (1999) which stated that men are more likely to be founders of new business and Kolvereid (1996) which indicated that men have higher entrepreneurial intentions compared to women. Study by Indarti and Langerberg (2004) on the contrary found no relation between gender and business success. Meanwhile study by Prijadi and Desiana (2017) indicates in the case of Indonesia, SMEs run by female entrepreneur will have higher sales but not higher profit and in the case of UK small listed firm, female directors has positive effect on firm performance (Pasaribu, 2017).

The second dummy variable was external finance. Firm with external finance will have 1.569 times higher probability of market expansion and 0.406 higher share of product sold outside the district. This finding is supported by the study of Kristiansen, Furuholt and Wahid (2003) on internet cafe in Indonesia, they found that small and medium internet cafe with external finance, including family and third party investment, have higher level of success. In addtion, Indarti and Langerberg (2004) also found that firms outside investment (i.e family investment) are more successful.

Table 2. Determinants of market expansion

\begin{tabular}{|c|c|c|c|c|}
\hline \multirow{2}{*}{ Variables } & \multicolumn{2}{|c|}{ Logit } & \multicolumn{2}{|c|}{ Tobit } \\
\hline & Odds Ratio & $\mathrm{p}$-value & Coefficient & p-value \\
\hline Constant & $0.033 * * *$ & & $-3.114 * * *$ & 0.000 \\
\hline No of years established & 1.000 & 0.998 & 0.003 & 0.195 \\
\hline Age of entrepreneur & 1.001 & 0.676 & -0.002 & 0.411 \\
\hline Education of entrepreneur & $1.065 * * *$ & 0.000 & $0.047 * * *$ & 0.000 \\
\hline Number of labor & $1.159 * * *$ & 0.000 & $0.153 * * *$ & 0.000 \\
\hline Value of production & $1.006 * * *$ & 0.000 & $0.001 * * *$ & 0.009 \\
\hline Dummy gender & $1.327 * * *$ & 0.000 & $0.329 * * *$ & 0.000 \\
\hline Dummy external finance & $1.569 * * *$ & 0.000 & $0.406 * * *$ & 0.000 \\
\hline Dummy partnership & 0.896 & 0.170 & -0.056 & 0.391 \\
\hline Dummy location & $1.289 * * *$ & 0.000 & $0.175 * * *$ & 0.000 \\
\hline No of observation & 21,380 & & 21,380 & \\
\hline Wald $\mathrm{Chi}^{2}$ & $910.08 * * *$ & 0.000 & $91.52 * * *$ & 0.000 \\
\hline Pseudo R ${ }^{2}$ & 0.080 & & 0.058 & \\
\hline
\end{tabular}

Note: ${ }^{* * *}$ significant at $1 \%$ level; $* *$ significant at $5 \%$ level; $*$ siginificant at 10 level 
The last was the dummy for location which is a proxy of infrastructure condition. Micro and small firm located in Java island had 1.289 times higher probability of market expansion and 0.179 higher share of product sold outside the district. This can be explained since the condition of infrastructure in Java island is better than outside the Java island; therefore, it is cheaper and easier to conduct market expansion in Java island. Rodriguez-Pose et al. (2013) showed that location of province in Indonesia makes an important difference in firm's export propensity since different location has different transportation infrastructure. For farmers, Shilpi and Umali-Deininger (2008) showed that better infrastructure will make farmers expand their product market by selling to the nearest market rather than in the farm gate.

Looking at the coefficient on both models, the external finance variable had the highest coefficient. Helping micro and small enterprises with external finance will give them higher probability to conduct market expansion since the activity needs resource in order to fulfill the market expansion activities.

There were three insignificant variables, namely firm establishment, the age of entrepreneurs and dummy for partnership. Older firms most probably have experience in running the business including market expansion but the result was not significant which is also contrary to the findings of Kristiansen, Furuholt, and Wahid (2003) which found that older firms will have more probability to be more successful. Majumdar (1997) also indicated that older firm in India is more productive but less profitable compared to newer firms. On the contrary, Prijadi and Desiana (2017) found in the case of SME's in Indonesia that younger firm will have higher sales and profit.

Age of entrepreneurs was insignificant which is supported by Indarti and Lagenberg (2004) indicated that there was no significant relationship between age and business success. Dummy for partnership was not significant which can be explained that most of the partnership conducted by micro and small enterprise is in the form of subcontracting activities and most of the subcontracting activities are mainly in the manufacturing sector such as automotives, metal, etc (Tambunan, 2008b).
From the two models, the determinants of market expansion can be classified into two categories those are internal and external of which both categories have different policy implication. In the internal aspects: education, firm size and location are the main determinants. In order to conduct market expansion, micro and small enterprises must increase their size and increase the education level of the entrepreneur. Meanwhile, the quality of infrastructure outside Java island must be improved to support the micro and small enterprise market expansion. Furthermore, the external factor is the external finance. The micro and small enterprise must be upgraded by providing additional capital in order to expand their market.

\section{Managerial Implication}

These micro and small enterprise in the future hopefully can grow into larger enterprise and contribute to the economy. From the results, it can be inferred that in order to make firm to conduct market expansion needs support in two aspects, increasing economic of scale and access to external finance. Increasing the firm's scale will make them more efficient in production and be able to compete in the market. The support to increase the scale can be in the form of increasing the firm's capacity through trainings. Meanwhile support on access to external finance can be in two forms. Firstly, through trainings in order to make them more bankable and secondly to connect these enterprises with banks.

\section{CONCLUSIONS AND RECOMMENDATIONS}

\section{Conclusions}

The significant determinants of market expansion were education level, number of labor, value of production, enterprise with external finance, enterprise located in Java and male-owned firm. Moreover, the same variables will also increase the share of product sold outside the district. From the significant variables, it can be inferred that market expansion is more affected by the firm's characteristics rather than entrepreneurial characteristics. 


\section{Recommendations}

Policy must be addressed in two aspects in order to upgrade the micro and small enterprises, the first is increasing the scale of the enterprises and secondly, fostering financial inclusion for these enterprises.

\section{REFERENCES}

Arinloye DAA et al. 2014. Marketing channel selection by smallholder farmers. Journal of Food Products Marketing 21(4): 337-357. https://doi.org/10.10 80/10454446.2013.856052.

Aristei D, Castellani D, Franco C. 2013. Firms' exporting and importing activities: Is there a twoway relationship?. Review of World Economy 149: 55-84.https://doi.org/10.1007/s10290-0120137-y.

Bas M, Strauss-Kahn V. 2010. Does importing more inputs raise export? Firm level evidence from France. MPRA Paper 27315.

Bernard AB, Jensen JB. 1999. Exceptional exporter performance: cause, effect, or both?. Journal of International Economics 47: 1-25. https://doi. org/10.1016/S0022-1996(98)00027-0.

Bhavani TA, Tendulkar SD. 2001. Determinants of firm-level export performance: a case study of Indian textile garments and apparel industry. Journal of International Trade and Economic Development 10: 65-92. https://doi. org/10.1080/09638190122431.

Brewer P. 2001. International market selection: developing a model from Australian case studies. International Business Review 10(2): 155-174.https://doi.org/10.1016/S09695931(00)00049-4.

Brouthers LE, Nakos G. 2005. The role of systematic international market selection on small firms' export performance. Journal of Small Business Management 43(4): 363-381. https://doi. org/10.1111/j.1540-627X.2005.00142.x.

Byford L, Henneberry D. 2006. Export decisions of food processing firms in Kansas, Missouri and Oklahoma. Agribusiness 12: 247-264.

Doll JP, Orazem F. 1984. Production economics: theory with application 2nd Edition. New York: Wiley.

Faschamps M, Hill RV. 2005. Selling at the farmgate or travel to market. American Journal of Agricultural Economics 87(3): 717-734. https:// doi.org/10.1111/j.1467-8276.2005.00758.x.
Gujarati D. 2015. Econometrics by example. New York: Palgrave. https://doi.org/10.1007/978-1137-37502-5.

Indarti N, Langenberg M. 2004. Factors affecting business success among SMES: empirical evidences from Indonesia. Paper presented at The second Bi-annual European Summer University 2004, University of Twente, Enschede, The Netherlands, September, 19-21st, 2004

Javalgi RG, White DS, Lee O. 2000. Firm characteristics influencing export propensity: an empirical investigation by industry type. Journal of Business Research 47: 217-228. https://doi. org/10.1016/S0148-2963(98)00065-4.

Kolvereid L. 1996. Prediction of employment status choice intentions. Entrepreneurship Theory and Practice Fall 21(1): 47-57. https://doi. org/10.1177/104225879602100104.

Kristiansen S, Furuholt B, Wahid F. 2003. Internet cafe entrepreneurs: pioneers in information dissemination in Indonesia. The International Journal of Entrepreneurship and Innovation 4(4): 251-263. https://doi. org/10.5367/000000003129574315.

Lee J, Habte-Giorgis B. 2004. Empirical approach to the sequential relationships between firm strategy, export activity, and performance in U.S. manufacturing firms. International Business Review 13: 101-129. https://doi.org/10.1016/j. ibusrev.2003.05.003.

Majumdar SK. 1997. The impact of size and age on firm level performance: some evidence from India. Review of Industrial Organization 12: 231-241. https://doi.org/10.1023/A:1007766324749.

Mazzarol T et al. 1999. Factors influencing small business start-ups. International Journal of Entrepreneurial Behaviour and Research 5(2): 48-63. https://doi. org/10.1108/13552559910274499.

McMahon RGP. 2001. Growth and performance of manufacturing SMEs: The influence of financial management characteristics. International Small Business Journal 19(3): 10-28. https://doi. org/10.1177/0266242601193001.

Ministry of Cooperative and Small Medium Enterprise. 2014. Number of Micro, Medium and Large Enterprise. Ministry of Cooperative and Small Medium Enterprise.

Panda RK, Sreekumar. 2012. Marketing channel choice and marketing efficiency assessment in agribusiness. Journal International Food \& 
Agribusiness Marketing 24(3): 213-230. https:// doi.org/10.1080/08974438.2012.691812.

Pasaribu P. 2017. Female Directors and Firm Performance. Gadjah Mada International Journal of Business 19(2): 145-166. https://doi. org/10.22146/gamaijb.15619.

Pla-Barber J, Alegre J. 2007. Analysing the link between export intensity, innovation and firm size in a science-based industry. International Business Review 16: 275-293. https://doi.org/10.1016/j. ibusrev.2007.02.005.

Prijadi R, Desiana PM. 2017. Factor affecting the probability and growth of small and medium enterprise (SMEs) in Indonesia. International Journal of Economics and Management 11: 35-44.

Rodriguez-Pose A et al. 2013. Geography and the determinants of firm exports in Indonesia. World Development 44: 225-240. https://doi. org/10.1016/j.worlddev.2012.12.002.

Serra F, Pointon J, Abdou H. 2012. Factors influencing the propensity to export: A study of UK and Portuguese textile firms. International Business Review 21: 210-224. https://doi.org/10.1016/j. ibusrev.2011.02.006.

Silvente FR. 2005. Changing export status and firm performance: evidence from UK small firms. Applied Economics Letters 12: 567-571. https:// doi.org/10.1080/13504850500120649.
Sinha TN. 1996. Human factors in entrepreneurship effectiveness. The Journal of Entrepreneurship 5(1): 23-39. https://doi. org/10.1177/097135579600500102.

Sjohlom F. 2003. Which Indonesian firms export? The importance of foreign networks. Regional Science 82: 333-350. https://doi.org/10.1007/ s10110-003-0163-1.

Statistics Indonesia. 2015. Micro and Small Enterprise Profile. Jakarta: Statistics Indonesia.

Storey D. 1994. Understanding the Small Business Sector. London: Routledge.

TambunanT. 2008a. SMEs development in Indonesia: do economic growth and government support matter? International Journal of Asia Pacific Studies 4(2): 1-18.

Tambunan T. 2008b. SME Development in Indonesia with Reference to Networking, Innovativeness, Market Expansion and Government Policy', in Lim, H. (ed.), SME in Asia and Globalization, ERIA Research Project Report 2007-5: 99-131.

Westhead P, Wright M, Ucbasaran D. 2002. International market selection strategies selected by "micro" and "small" firms. International Journal of Management Science 30(1): 51-68. https://doi. org/10.1016/S0305-0483(01)00056-1.

Yip GS, Biscarri JG, Monti JA. 2000. The role of the internationalization process in the performance of newly internationalizing firms. Journal of International Marketing 8(3): 10-35. https://doi. org/10.1509/jimk.8.3.10.19635. 